\title{
Sustainable development of agriculture in a large industrial region
}

\author{
Aleksey Ilukhin*, and Svetlana Ilukhina \\ Ural State University of Economic, 8 Marta str./Narodnoy Voli, 62/45, Yekaterinburg, Russia
}

\begin{abstract}
The study provides an assessment of the state and prospects of sustainable agriculture in a large industrial region, which is the Sverdlovsk region, as the basis for its sustainable development in the new economic realities generated by the global pandemic of 2020 associated with the threats of COVID-19. The hypothesis of the study is the assumption that the sustainable development of agriculture in the region in the new conditions is provided by the accumulated economic potential in the conditions of the coronacrisis contradictions trigger. The purpose of the study is a comprehensive assessment of the real potential and level of food supply in the Sverdlovsk region, which is provided by agricultural producers, based on the analysis of their numerical composition, geographical location and the allocation of the structural orientation of their activities, the dynamics of its development in the context of new strategic challenges. An economic and statistical study of the agricultural sector of the economy of a large industrial region, the Sverdlovsk region, was conducted. To ensure representativeness, 143 agricultural producers were studied and the existing enterprises of the Sverdlovsk region were grouped as of 01.09.2020.
\end{abstract}

\section{Introduction}

The food security of the country and its individual regions is undoubtedly based on the sustainable development of agriculture. This is especially true for large industrial regions of Russia, which include the Sverdlovsk region. An assessment of the level of development and potential of agricultural production provides an understanding of specific measures that ensure its sustainable development.

The solution of these problems is an integral part of national security; their assessment and current analysis are enshrined in the Food Security Doctrine of the Russian Federation [1] and the Action Plan of the Government of the Russian Federation for the implementation of the provisions of the Food Security Doctrine of the Russian Federation [2]. These documents directly indicate the relationship between the food independence of our country and its self-provision, the main types of domestic agricultural products, raw materials and food. In order to assess its state, a system of indicators is used, such as: the competitiveness of enterprises, the level of production and consumption of agricultural products.

\footnotetext{
*Corresponding author: iluhiaa@usue.ru
} 
The socio-economic processes caused by the global COVID-19 pandemic are a new global factor that focuses on achieving conditions for sustainable agricultural development. The main criteria for sustainable development according to the UN methodology are balanced and safe socio-economic and spatial well-being, social development, the formation of a competitive economy based on institutional economic freedom [3,4]. The solution of the problems of sustainable development in the current conditions is possible on the basis of the accumulated socio-economic potential, and the social losses associated with the global pandemic should be considered as an additional challenge, a motivational factor for actions to ensure sustainable development [5].

The problems of sustainable development and economic growth are actively studied by Russian and foreign economists. Among them, the following authors can be mentionned: R. S. Greenberg, D. E. Sorokin [6], E. G. Animitsa, Ya. P. Silin [7, 8, 9], A. I. Tatarkin [10], Kristof V. A., Hornidge A. K. [11], N. Ward, D. L. Brown [12], all of them emphasize that the accumulated potential and nano-technologies provide the basis for the sustainable development of the entire economy and agriculture.

\section{Materials and Methods}

In order to adequately and comprehensively assess the real potential and level of food supply provided by agricultural producers, it is necessary to analyze their number, geographical location and to identify the structural orientation of their activities in order to ensure the most effective and promising of them.

Rural areas have lost their attractiveness, including due to the imperfect mechanism of economic incentives. The number of peasant (farmer), personal subsidiary farms, NGOs, and individual entrepreneurs in Russia as a whole decreased by $40 \%$ on average over the period 2006-2016 [13].

On the basis of these provisions, an economic and statistical study of the agricultural sector of the economy of a large industrial region, the Sverdlovsk region, was conducted. To ensure representativeness, 143 agricultural producers were studied, and the existing enterprises of the Sverdlovsk region were grouped as of 01.09.2020. We also conducted an analysis of these enterprises, expanding the list by including inactive enterprises in it. Since it seems appropriate to analyze the reasons why they closed down and perhaps in the future, the authorities will be able to find investors to resume their activities.

63 active agricultural enterprises were selected from the available data, which is $44 \%$ [14]. The data was sorted according to the grouping feature - "enterprises belonging to an administrative territorial unit", and then a structural analysis was carried out (Fig. 1): 


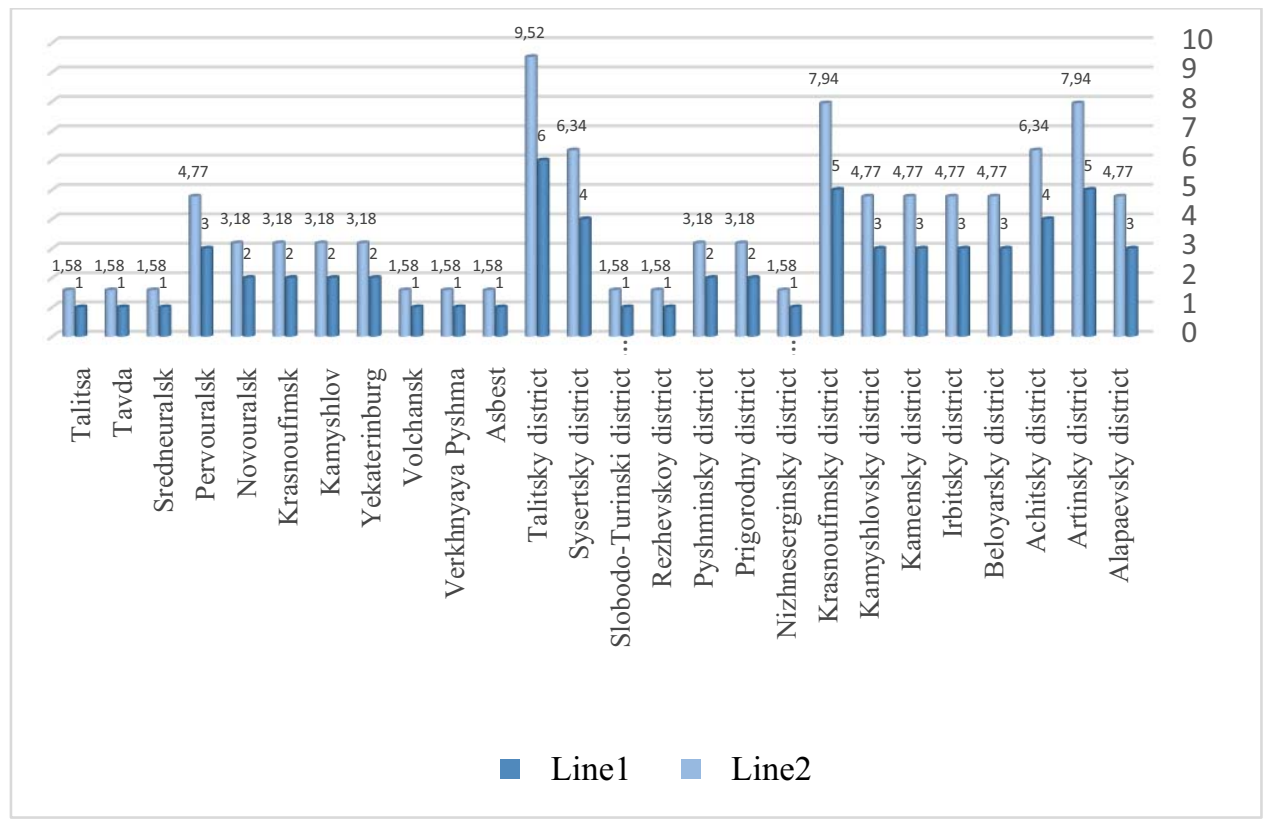

Fig. 1. Structural analysis of agricultural enterprises of the Sverdlovsk region by belonging to the administrative territorial unit - "district".

\section{Results and Discussion}

The obtained results indicate that $73 \%$ of enterprises engaged in the production of agricultural products are mainly located in the districts of the region. Agricultural activity is most developed in the Talitsky district, where 9,52\% of such enterprises of the Sverdlovsk region are located, Krasnoufimsky and Artinsky-7,94\%, in Nizhneserginsky, SlobodaTurinsky-1,58 \%. It should also be taken into account that there are more active enterprises in areas with a predominance of rural areas over urban areas.

The structural analysis of the activities of agricultural enterprises is presented in the diagram (Fig. 2): 


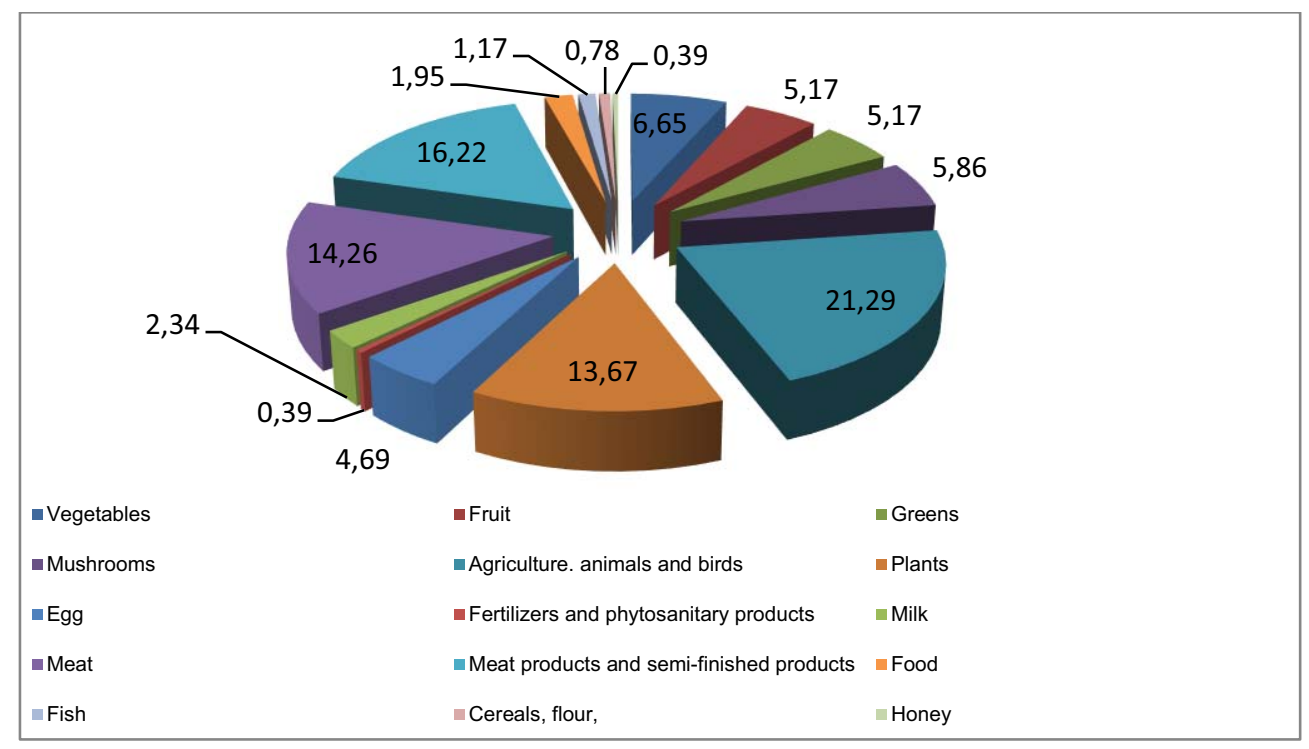

Fig. 2. Structural diagram of agricultural enterprises of the Sverdlovsk region in the areas of activity (meat, milk, etc.) in \% of the total for 1.09 .2020

The diagram shows that enterprises have about 15 directions in the development of their business, some combine several ones. The largest share is taken by the direction of agricultural animals and birds, the second place is taken by meat products and semifinished products. Crop production is practically not developing, as enterprises are closing down. Losses by 1.01.2020 in the number of enterprises in the areas of economic activity were: vegetables, fruits, herbs, mushrooms, feed $-0,78 \%$ each, meat and products $-3,13 \%$ each, animals and birds $-4,69 \%$, plants $-3,52 \%$, cereals, flour $-0,39 \%$.

\section{Conclusions}

The analysis of the activities of the enterprises showed that $44,45 \%$ of them are engaged in the production and sale of meat and meat products. As well as a large number of enterprises that are engaged in mixed production of meat, milk, grain and grain crops, this amounted to $27 \%$. The least number of enterprises turned out to be in such areas of activity as fish production, fruit and vegetable production and canning, production of medicinal, leather, and wild raw materials.

The largest number of enterprises is concentrated in Krasnoufimsky district - 5,59\%, Alapaevsky district - 5,59\%, Talitsky district - 4,9\%, Kamensky district $-4,2 \%$ and Yekaterinburg $-4,2 \%$. The spread by cities and villages was: in 47 municipalities (cities, towns, etc.) $0,7 \%$ of the total number, in $14-1,4 \%$, in $4-2,1 \%$, in $3-3,5 \%$, in $1-4,9 \%$, in $2-2,8 \%, 4,2 \%, 5,59 \%$, respectively. We observe that agricultural enterprises are scattered in the Sverdlovsk region, there are no certain areas with large clusters, and this indicates the operation of the territorial commodity market and the impossibility of forecasting it.

The main indicator of sustainable development developed by the World Bank is the "true investment standards" [1]. The Sverdlovsk region has accumulated a huge investment potential, which is not fully realized due to insufficient investment. Despite a $1,3 \%$ reduction in fixed capital investment in 2019-2020, there is a $17 \%$ increase in equity, and the region confidently ranks 5th among the 85 subjects of the Russian Federation in this indicator. Among other areas of investment policy in the Sverdlovsk region, it is planned to 
"develop a system of tax benefits, as well as preferential conditions for the use of land and other natural resources" [15]. Together with the current targeted programs, will undoubtedly have a positive impact on the quality of life of the region's population and contribute to the sustainable economic development of the territory. The main driver of economic growth can be the development of the agro-industrial complex of the Sverdlovsk region, if you increase the share of labor resources in rural areas, while using the redirected flows of migrants.

\section{References}

1. The Doctrine of Food Security of the Russian Federation, approved by Presidential Decree No. 20 of January 21, 2020, http://www.kremlin.ru/

2. Action Plan ("road map") for the implementation of the provisions of the Food Security Doctrine of the Russian Federation, http://static.government.ru/

3. Working list of indicators of the UN Commission on Sustainable Development, https://sustainabledevelopment.un.org/

4. D. H. Meadows, D. L. Meadows, J. Randers, W.W. Behrens III, The Limits To Growth. A Report For The Club Of Rome's Project On the Predicament Of Mankind (1972)

5. A. Ilyukhin, S. Ponomareva, S. Ilyukhina, E3S Web of Conferences 208, 03006 (2020) IFT 2020

6. S.D. Bodrunov, R.S. Grinberg, D.Ye. Sorokin, Economic revival of Russia, 1(35) (2013)

7. Ya.P. Silin, E.G. Animitsa, J. of New Economy, 21(1) (2020)

8. Ya.P. Silin, E.G. Animitsa, N.V. Novikova, Economy of the region, 13(3) (2017)

9. Ya.P. Silin, E.G. Animitsa, N.V. Novikova, Economy of the region, 12(3) (2016)

10. A.I. Tatarkin, Economic revival of Russia, 2(44) (2015)

11. Kristof V.A., Hornidge A.K. Knowledge \& expertise in governance, Wageningen Academic Publishers, Wageningen, (2015)

12. Neil Ward \& David L. Brown. Regional Studies, 43, 1237 (2009)

13. All-Russian agricultural censuses of 2006 and 2016, https://www.gks.ru/

14. Office of the Federal State Statistics Service for the Sverdlovsk Region and the Kurgan Region, http: //sverdl.gks.ru/

15. The plan to attract investment in the economy of the Sverdlovsk region for 2020-2022. (Investment Council under the Governor of the Sverdlovsk Region), http://www.mir.midural.ru/ 